\section{THE ENDOCRINE ORGANS IN HEALTH AND DISEASE}

Essentials of Endocrinology

By Dr. Arthur Grollman. Pp. xvi+480. (Philadelphia, London and Montreal: J. B. Lippincott Company, 1941.) $36 s$.

TO science has developed more rapidly in recent years than that of endocrinology. This has been partly due to its great practical importance in relation to the study of disease, and it is noteworthy that many of the more important discoveries in this branch of science have had their origin in clinical observation. As Dr. Grollman points out, it is impossible to dissociate experimental from clinical endocrinology. Moreover, the latter can now be placed on a scientifically sound basis, for the organism is continually performing natural experiments the results of which can be followed up and correlated with other observed facts in such a way that conclusions of lasting value can be formed. It is the purpose of Dr. Grollman's book to bring together in one volume the results of all these observations and experiments for the average medical reader. At the same time, there is much in the work that makes a strong appeal to the general biologist.

The book is divided into five main parts. The first of these deals with the endocrine glands of the cranial cavity and more particularly with the hypophysis, which is a compound gland of great importance but not necessarily the 'master gland' of the endocrine system as some authors have conceived it to be. It is pointed out that certain disorders of hypothalamic origin have often been ascribed to the pituitary. Thus the well-known 'fat boy' condition may be hypothalamic. Nevertheless, the fact that stimuli of various sorts applied to the hypothalamus may affect the functions of the anterior pituitary, both positively and negatively, is evidence that hypothalamic lesions or defects may very often make themselves evident by interfering with pituitary function. In this part of the book the diseases ascribed to pituitary influence are well described and illustrated.

The second part deals with the branchiogenic organs and contains admirable accounts of the thyroid and parathyroid glands and the diseases arising from their dysfunction. The thymus is also included in this part, and after carefully considering the evidence, the author comes to the conclusion that none of the theories which have been put forward to explain its function are based on adequate experimental data or any plausible foundation. Some of the experimental evidence is contradictory as, for example, the claim that irradiation of the thymus in rats causes testicular atrophy, and the conclusion of Noel Paton that thymectomy tends to produce testicular hypertrophy.

Part 3 of the book is upon the endocrine organs of the abdominal cavity, namely, the 'islet' tissue of the pancreas and the medulla and cortex of the supra-renal. The pathology of these organs and their relationship to other organs and structures are well described, and much useful information is given concerning the treatment of the diseases connected with these organs. In dealing with the adrenals, there is a short account of their comparative anatomy throughout the vertebrates, but there is no mention of Swale Vincent, to whom much of our knowledge was due.
The fourth part, which concerns the reproductive system, is the least satisfactory in the book. Heape's original terminology used in describing the phases of the ostrous cycle is adopted with some modifications, but his name is not mentioned and the modifications do not make for increased accuracy. Thus, the annestrum and diœstrum are not identical, and the latter is scarcely a period of rest since it is actually an abbreviated pseudo-pregnancy occurring only in polyœstrous mammals, and the distinction between these and monœstrous animals is not made. Ovulation does not necessarily depend upon coition in the cat, since many cats ovulate spontaneously during heat and are polyœstrous. Besides the rabbit and the ferret, the thirteen-lined ground squirrel (among rodents) does not ovulate without previously copulating, as shown by Foster. Moreover, among primates, both man and monkeys, there may be nonovulatory diœstrous cycles and there is evidence that occasionally in women coition may induce ovulation. There is no such thing as a diœstrous period in the dog. Animals, such as most ruminants in temperate countries, which experience ostrus in autumn, usually bring forth in late winter or spring without any postponement of the development of the embryo. There is no evidence of a physiological law that the right and left ovaries of mammals produce ripe follicles which discharge their eggs alternately, but as a matter of actual fact this happens more frequently than not in the cow as recorded by Hammond and in the mare as observed by Day, and so probably may happen in other mammals. The placental theory of parturition does not explain the phenomena of pseudo-parturition as seen in the bitch, the rabbit and the marsupial cat. The absence of any account of behaviour cycles in relation to recurrent sexual phenomena is a noticeable omission.

The work concludes with a short fifth part on hormones produced from primarily non-endocrine organs, with notes on invertebrate and plant hormones.

About the general usefulness of the book there can be no question. $\quad$ F. H. A. Marshall.

\section{SCIENTIFIC CHILD-STUDY}

\section{Child Psychology}

Child Development and Modern Education. Edited by Charles E. Skinner and Philip Lawrence Harriman, with the collaboration of Amy F. Arey, Lawrence Augustus Averill, Lorin E. Bixler, Elden A. Bond, John W. Charles, Lester D. Crow, Raleigh M. Drake, Clyde Hissong, Clarence E. Ragsdale, Gladys Risden, J. J. Smith, Brian E. Tomlinson. Pp. xii +522 . (New York: The Macmillan Company, 1941.) $12 s .6 d$. net.

THE dominant note of this book, and the justification of review in the pages of NATURE, is its claim, consistently maintained throughout, to adhere to a strictly scientific treatment of its subject. Poets and philosophers long held the field in the treatment of childhood, but since Darwin's time the man of science has joined them. Even the man of science has sometimes succumbed to points of view that could scarcely be ealled scientific, and the progress of ehild psychology has been from armchair speculation to the careful experimentation which is the sole 